\title{
Effects of chromium-enriched bacillus subtilis KT260179 supplementation on chicken growth performance, plasma lipid parameters, tissue chromium levels, cecal bacterial composition and breast meat quality
}

Jiajun Yang, Kun Qian*, Wei Zhang, Yayuan Xu and Yijing Wu

\begin{abstract}
Background: Both chromium $(\mathrm{Cr})$ and probiotic bacillus own the virtues of regulating animal metabolism and meat quality. Purpose of this study was to evaluate the efficiency of supplemental $\mathrm{Cr}$ and bacillus in the form of chromium-enriched Bacillus subtilis KT260179 (CEBS) on chicken growth performance, plasma lipid parameters, tissue chromium levels, cecal bacterial composition and breast meat quality.

Methods: Six hundred of 1-day-old Chinese Huainan Partridge chickens were divided into four groups randomly: Control, inorganic Cr, Bacillus subtilis, and CEBS. The feed duration was 56 days.

Results: After 28 days of treatment, broiler feed CEBS or normal B. subtilis had higher body weights than control broiler, and after 56 days, chickens given either CEBS or B. subtilis had greater body weights than control broiler or those given inorganic Cr. Plasma total cholesterol, triglycerides, and low density lipoprotein cholesterol levels declined significantly in the CEBS group compared with the control, whereas plasma high density lipoprotein cholesterol levels increased significantly. The concentration of $\mathrm{Cr}$ in blood and breast muscle increased after CEBS and inorganic $\mathrm{Cr}$ supplementation. B. subtilis and CEBS supplementation caused a significant increase in the numbers of Lactobacillus and Bifidobacterium in the caecum, while the numbers of Escherichia coli and Salmonella decreased significantly compared to the control. Feed adding CEBS increased the lightness, redness, and yellowness of breast meat, improved the water-holding capacity, decreased the shear force and cooking loss.
\end{abstract}

Conclusions: In all, CEBS supplementation promoted body growth, improved plasma lipid parameters, increased tissue Cr concentrations, altered cecal bacterial composition and improved breast meat quality.

Keywords: Chromium-enriched bacillus subtilis, Chicken, Growth performance, Meat quality, Bacterial composition

\footnotetext{
*Correspondence: yjj1984112@outlook.com

The Institute of Animal Husbandry and Veterinary Medicine, Anhui Academy

of Agricultural Sciences, No. 40 Nongke South Road, Hefei 230031, Anhui,

People's Republic of China
} 


\section{Background}

With the application of modern breeding technology, the major biological characteristics of chickens or broilers, i.e. growth performance, daily weight gain, feed conversion efficiency and resistance to disease, have been improved significantly [1]. Despite the success of breeding programs in increasing meat production, the high selection intensity has resulted in negative impacts on growth performance and meat quality $[2,3]$.

Chromium $(\mathrm{Cr})$ is an essential trace element and its beneficial effects on health are well documented in humans and animals [4]. Adding suitable dose of $\mathrm{Cr}$ to diet could improve the meat quality and regulate the metabolism of nutrient substances in animals [5]. Supplementation of the diet with trivalent $\mathrm{Cr}$ [Cr (III)] can be achieved using the salt chromium trichloride $\left(\mathrm{CrCl}_{3}\right)$. Low molecular weight organic $\mathrm{Cr}$ complexes, such as picolinic acid and nicotinate salt forms, provide a myriad of benefits with higher organic bioavailability than the inorganic forms that are most often used as a dietary supplement [6]. Although $\mathrm{Cr}$ nanocomposites have even higher bioavailability than organic sources of $\mathrm{Cr}$ [7], their greater cost has inhibited widespread use. In animal husbandry, there is a need to explore a cheap and convenient organic source of $\mathrm{Cr}$ for use in industrial applications.

Bacillus subtilis is a probiotic bacterium that is widely used in diets of both humans and animals [8]. Oral administration of B. subtilis can exert a range of beneficial effects, including improvement of growth, enhancement of meat characteristics, optimizing the balance of intestinal microbiota, prevention and treatment of some diarrheal diseases, and reduction of serum cholesterol $[9,10]$. For these reasons, $B$. subtilis has attracted considerable attention as a potentially beneficial dietary supplement for animal health.

It might be worthwhile to explore whether the combined use of organic $\mathrm{Cr}$ and B. subtilis might have a greater effect on regulating body growth and metabolism. Chinese Huainan Partridge chicken is a native breed in South of China. Because of special consumed habits, South of Chinese liked to choose the breed of broiler. Hence, Chinese Huainan Partridge chicken was employed to carry out this study. To test this hypothesis, we produce $\mathrm{Cr}$-enriched B. subtilis (CEBS) which combines the virtues of $B$. subtilis and those of organic $\mathrm{Cr}$ and might induce an enhanced response to dietary supplementation. The aim of our study was to determine whether CEBS supplementation could play a role in improving body growth performance and breast meat quality, through improving lipid metabolism, utilization of $\mathrm{Cr}$ and intestinal bacterial composition on Chinese Huainan Partridge chicken.

\section{Methods}

\section{Chicks, diets, and experimental design}

The experimental protocol used in this study, including animal management, housing, and slaughter procedures, was approved by the Institution of Animal Science and Welfare of Anhui Province (Number: IASWAP2014110528). A total of 600 1-day-old Chinese Huainan Partridge chicken were randomly allocated into four groups with six replicate of 25 each. Chickens in the control group were fed basal feedstuff; the three treatments were fed basal feedstuff with different additives. Experimental diets were fed in two periods: starter (day 0-28) and finisher (day 29-56). The composition and nutrient analysis results for the basic diet are shown in Table 1. All the nutrients met or exceeded the nutrient requirements as recommended by the NRC [11]. The birds had free access to water and feed. In the whole trial, the normal immune procedure was implemented. B. subtilis KT260179 (submitted to National Center for Biotechnology Information) was provided by the Institute of Animal Husbandry and Veterinary Medicine, Anhui Academy of Agricultural Sciences in China. The fermentation of $B$. subtilis KT260179 and CEBS was followed Yang et al. (CEBS: Total Cr concentration $30 \mu \mathrm{g} / \mathrm{g}$, Organic Cr $29.17 \mu \mathrm{g} / \mathrm{g}$, Live B. subtilis KT260179 $\left.1.0 \times 10^{9} \mathrm{CFU} / \mathrm{g}\right)$. After fermented, CEBS were harvested and added to mass

Table 1 Composition and nutrient analysis of the basic diet for broilers at different stages (\% as fed)

\begin{tabular}{llll}
\hline & Ingredient & $\begin{array}{l}\text { Starter } \\
(0 \sim 28) \%\end{array}$ & $\begin{array}{l}\text { Finisher } \\
(29 \sim 56) \%\end{array}$ \\
\hline Item & Corn & 57.97 & 61.75 \\
& Soybean meal & 29.30 & 26.45 \\
& Fish powder & 5.00 & 3.51 \\
& Soybean oil & 2.00 & 3.00 \\
& Premix* & $5.00^{\mathrm{a}}$ & $5.00^{\mathrm{a}}$ \\
& Dicalcium phosphorus & 0.47 & 0.29 \\
& Limestone & 0.26 & 0 \\
& Metabolizable energy & 12.12 & 12.54 \\
& (MJ/kg) & & \\
& CP & 21 & 19 \\
& Calcium & 1 & 0.9 \\
& Total phosphorus & 0.68 & 0.65 \\
& Available phosphorus & 0.45 & 0.38 \\
& Lys & 1.05 & 0.9 \\
& Met & 0.46 & 0.3
\end{tabular}

The premix provides

a vitamins and trace elements per kg diet: Vitamin A (retinyl acetate) 9, $875 \mathrm{IU}$, Vitamin $\mathrm{D}_{3}$ (cholecalciferol) 3, $000 \mathrm{IU}$, Vitamin E (DL-a-tocopheryl acetate) $20 \mathrm{IU}$, menadione $3.25 \mathrm{mg}$, Vitamin $\mathrm{B}_{12}$ (cyanocobalamin) $0.025 \mathrm{mg}$, thiamin $1.5 \mathrm{mg}$, riboflavin $5.0 \mathrm{mg}$, biotin $0.032 \mathrm{mg}$, folacin $1.25 \mathrm{mg}$, niacin $12 \mathrm{mg}$, pantothenic acid $12 \mathrm{mg}$, and pyridoxine $3.75 \mathrm{mg}$, manganese $100 \mathrm{mg}$, zinc $80 \mathrm{mg}$, iron $80 \mathrm{mg}$, copper $8 \mathrm{mg}$, iodine $0.15 \mathrm{mg}$, and selenium $0.15 \mathrm{mg}$ 
feed followed $0.67 \%$. First, we added 0.67 L liquid CEBS to $9.33 \mathrm{~kg}$ mass feed and mixed with hand, then the mixed mass feed was added into blender contained $90 \mathrm{~kg}$ mass feed. The blender was employed for $20 \mathrm{~min}$ to mix the additives uniformity. The ways of B. subtilis KT260179 and inorganic $\mathrm{Cr}$ supplementation was the same as the CEBS. The ratio of B. subtilis KT260179 (Live B. subtilis KT260179 $2.0 \times$ $10^{9} \mathrm{CFU} / \mathrm{g}$ ) supplemented was $0.34 \%$. We prepared the inorganic $\mathrm{Cr}$ solution and sterilized. Then, the $\mathrm{CrCl}_{3}$ solution was homogenize with mass feed. After prepared the four kinds of feedstuff, the population of $B$. subtilis was counted with plate method which yeast extract peptone dextrose medium was employed. Also, the concentration of $\mathrm{Cr}$ in four kinds of feedstuff was measured. The results were listed in Table 2 .

\section{Growth performance and sample collections}

Broilers in every replicate from each treatment group were weighed on day 0, 28, and 56. Daily feed consumption was accurately recorded. Daily weight gain and ratio of feed to gain $(\mathrm{F} / \mathrm{G})$ were calculated. $\mathrm{ADG}=$ body increase $(\mathrm{g}) /$ number of days. $\mathrm{F} / \mathrm{G}=$ mass of food intake (g)/body increase (g).

After 56 days, two chickens from each replicate were selected, fasted for $12 \mathrm{~h}$, and then tissues and blood were harvested under general halothane anesthesia. All blood samples were collected in $5.0 \mathrm{~mL}$ sterile heparinzed tubes. We removed $1 \mathrm{~mL}$ of each blood sample for measurement of $\mathrm{Cr}$ concentration. Then, remnant chick blood was centrifuged at $3000 \mathrm{~g}$ for $10 \mathrm{~min}$ to collect the plasma for biochemical assays (described below). Breast muscle was collected, which was frozen in liquid nitrogen and stored at $4{ }^{\circ} \mathrm{C}$ until analysis. The tissue of caeca from chickens was removed under aseptic conditions, which was stored in sterile plastic tubes in boxes packed with ice, and immediately sent to our laboratory for plate-counting of microorganisms.

\section{Plasma lipid analyses}

Chicken plasma total cholesterol (TC), triglycerides (TG), low density lipoprotein cholesterol (LDLC), and high density lipoprotein cholesterol (HDLC) concentrations

Table 2 Concentration of $\mathrm{Cr}$ and number of $B$. suthilis in Groups

\begin{tabular}{lcl}
\hline Groups & $\begin{array}{l}\text { Concentration of } \mathrm{Cr} \\
\text { (ng Cr/g feed) }\end{array}$ & $\begin{array}{l}\text { Number of B. suthilis } \\
\text { (colony-forming units/g feed) }\end{array}$ \\
\hline i (Control) & 60.0 & 0 \\
ii (Inorganic Cr) & 260.0 & 0 \\
iii (B. suthilis) & 60.0 & $6.7 \times 10^{6}$ \\
iv (CEBS) & 260.0 & $6.7 \times 10^{6}$ \\
\hline
\end{tabular}

were measured using the appropriate detection kits (Nanjing Jiancheng Bioengineering Institute).

\section{Tissue $\mathrm{Cr}$ assay}

A ZEEnit $700 \mathrm{P}$ atomic absorption spectrometer (Analytik Jena, Germany) was employed for assaying chromium levels in tissues. All the measurements were performed by the method described by Afridi et al. [12]. Samples of blood, breast meat $(0.2 \mathrm{~g})$, and $0.2 \mathrm{~g}$ feedstuff from all four groups were placed in beakers and digested by addition of $10 \mathrm{~mL}$ of a nitric acid-perchloric acid ( $\mathrm{HNO} 3-\mathrm{HClO} 4)$ mixture. The mixture was heated on a sand bath until fumes appeared (the temperature was controlled at $200{ }^{\circ} \mathrm{C}$ by monitoring of the sand) and the solution had mostly evaporated. After cooling, $5 \mathrm{~mL} \mathrm{HNO}_{3}$ was added, and the heating procedure was repeated at $180{ }^{\circ} \mathrm{C}$. The cooled remainder was made up to $10 \mathrm{~mL}$ with distilled water. Eight replicates were used for each group.

\section{Cecal sample collection and bacterial composition analysis}

The bacterial composition of ceaca in different treatments was done with plate method [13, 14] (eosin methylene blue agar for Escherichia coli, SalmonellaShigellaagar plate for Salmonella, de Man, Rogosa, and Sharpe agar for total Lactobacillus, and BLB agar for Bifidobacterium by pour plate method, including E. coli, Salmonella, total Lactobacillus, and Bifidobacterium which were repeated three times).

\section{Meat Quality Analysis}

Breast muscle samples were collected for meat quality at the end of the experiment. Lightness $\left(L^{*}\right)$, redness $\left(a^{*}\right)$, and yellowness $\left(b^{*}\right)$ of meat color was determined by a Chroma meter (model CR-410, Minolta Co., Tokyo, Japan). Water-holding capacity (WHC) was estimated by determining expressible juice using a modification of the filter paper press method described by Wierbicki and Deatherage [15] as follows. The breast meat were refrigerated overnight at $4{ }^{\circ} \mathrm{C}$ and then brought to room temperature before cooking to measure cooking loss and shear force. The breast meat from each bird was weighed and placed into a thin walled plastic bag, then cooked to an internal temperature of $70{ }^{\circ} \mathrm{C}$ on a digital thermostat water bath (HH-4, Jiangbo instrument, Jiangsu province, China) in a water-bath. Cooked meat was cooled to room temperature. The breast meat was weighed again for determination of cooking loss (\%). Cutting three 1.9 -mm-wide $\times 10 \mathrm{~mm} \times 10 \mathrm{~mm}$ strips from the center of the muscles parallel to the muscle fibers through the thickest portion of the cooked muscle to 


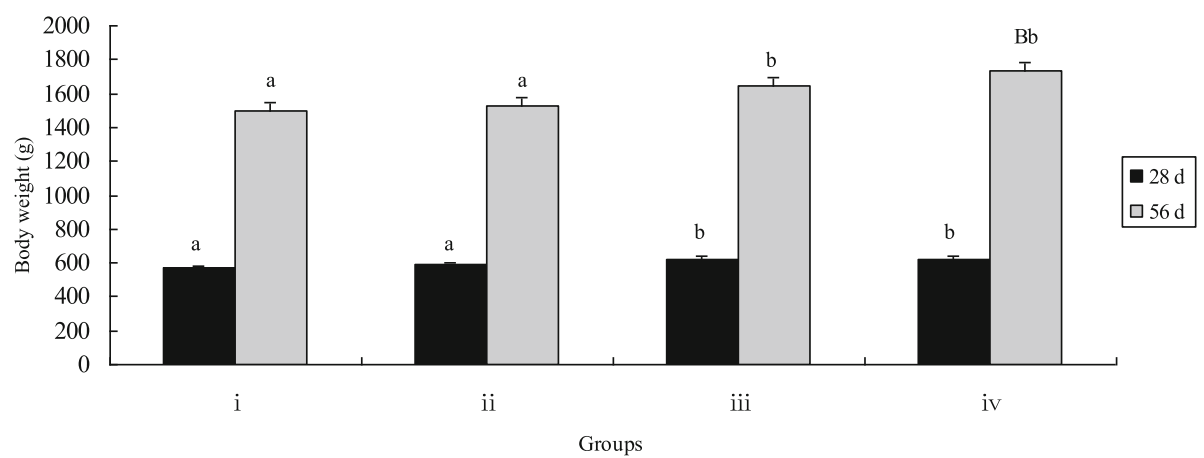

Fig. 1 Effects of different treatments on chicken body weight. The chicken were treated with control (i), inorganic Cr (ii), B. subtilis (iii) and CEBS (iv) after 28 and 56 days. Bars represent mean \pm S.E. Data of Body weight was statistically processed as REPEATED measurements. Bar in same color with different small letters a and b mean significant difference at 0.05 levels $(P<0.05)$. Aa, Bb mean significant difference at 0.01 levels $(P<0.01)$

measure meat shear force. The samples were cut perpendicular to the fiber direction using a Zwick Testing Machine Model Z2.5/TN1S (Zwick GmbH and Co, Germany) equipped with a Warner-Bratzler shear [16]. Peak force values were obtained in $\mathrm{kg} / \mathrm{mm}^{2}$.

\section{Statistical analysis}

Statistical analyses of the data were performed using SPSS 16.0 (SPSS, Inc., Chicago, IL, USA). Data are presented as means \pm standard error (SE). Differences between groups were compared using analyses of variance. Differences between means were assessed by the Tukey's honestly significant difference test of post hoc multiple comparisons. Data on Body weight, Average daily gain, Average daily feed intake and Ratio of feed to gain was statistically processed as REPEATED measurements. A $P$ value of less than 0.05 was considered statistically significant.

\section{Results}

\section{Growth performance}

Growth performance of Chinese Huainan Partridge chickens in different treatments was shown in Figs. 1, 2, 3 and 4. Chickens supplemented with B. subtilis KT260179 and CEBS owned higher final body weight than the control birds or those supplemented with inorganic $\mathrm{Cr}$ after 28 days $(P<0.05)$. The index of ADG among control, inorganic $\mathrm{Cr}$ and $B$. subtilis KT260179 supplemented groups was no significance $(P>0.05)$ at 28 days. While the result of F:G was opposite with the final body weight. Birds received B. subtilis KT260179 and CEBS had lower F:G $(P<0.05)$.

After 56 days, final body weights and ADG in CEBS group were significantly higher compared with the control and the inorganic $\mathrm{Cr}$ supplemented groups $(P<0.05)$ as well as the B. subtilis KT260179 group. While, the index of final body weight in group iv was highest of all $(P<0.05)$. Over the entire feeding duration, the

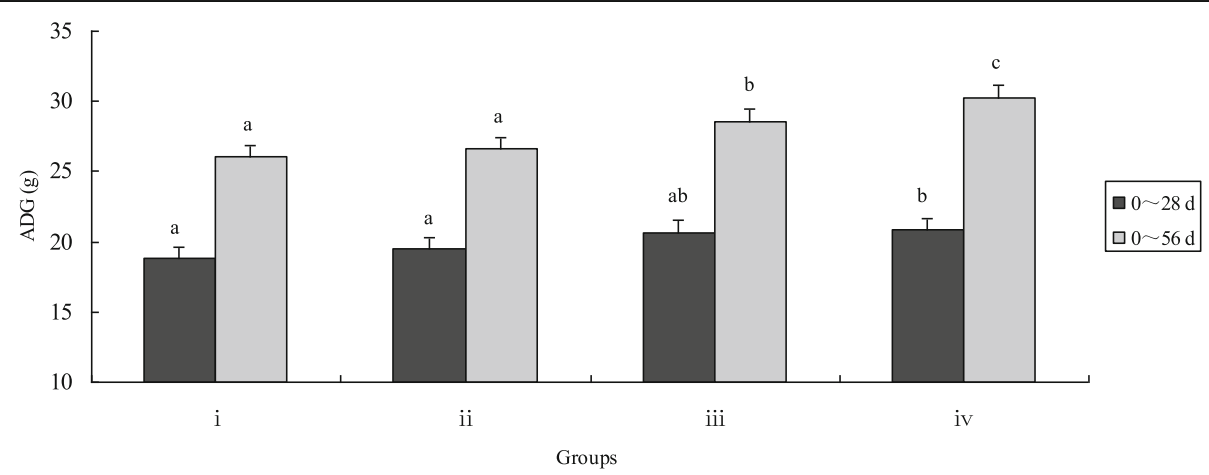

Fig. 2 Effects of different treatments on chicken average daily gain. The chicken were treated with control (i), inorganic $\mathrm{Cr}$ (ii), B. subtilis (iii) and CEBS (iv) after 28 and 56 days. Bars represent mean \pm S.E. Data of Body weight was statistically processed as REPEATED measurements. Bar in same color with different small letters a, b, c mean significant difference at 0.05 levels $(P<0.05)$ 


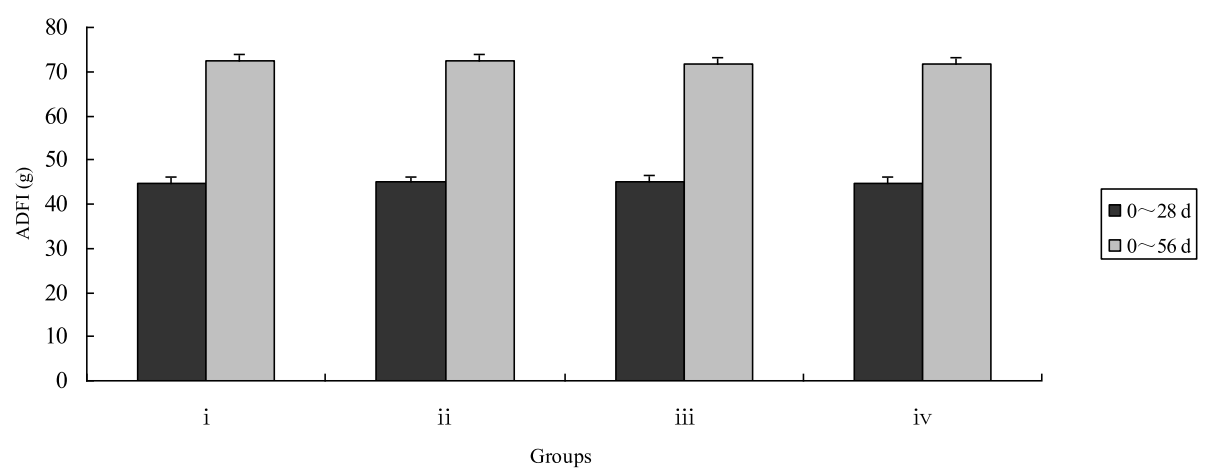

Fig. 3 Effects of different treatments on chicken average daily feed intake. The chicken were treated with control (i), inorganic Cr (ii), B. subtilis (iii) and CEBS (iv) after 28 and 56 days. Bars represent mean \pm S.E. Data of Body weight was statistically processed as REPEATED measurements. There were no differences among groups between 28 and 56 days $(P>0.05)$

F:G in the CEBS group was the lowest $(P<0.05)$. The F:G index of group iii was lower compared with the control and inorganic $\mathrm{Cr}$ groups $(P<0.05)$. There were no differences in the ADFI among the four groups either after 28 or after 56 days $(P>0.05)$.

\section{Plasma lipid parameters}

The results of plasma lipid parameters were listed in Table 3. The levels of lipids (TC, TG, LDLC) in chickens given B. subtilis KT260179 were significantly lower compared with the controls, but were still higher than those of the CEBS group $(P<0.05)$. The concentrations of HDLC in the plasma of chicken in the CEBS and B. subtilis KT260179 groups were higher compared with the control chicken $(P<0.05)$, the former being higher in CEBS than $B$. subtilis KT260179 treatment $(P<0.05)$. The ratio of TC:LDLC was calculated, which indicated that chicken supplemented with CEBS had the highest ratio of all $(P<0.01)$. Chicken supplied with B. subtilis KT260179 showed higher TC:LDLC compared with the control and inorganic $\mathrm{Cr}$ groups $(P<0.01)$. The results for the ratio of TC:HDLC was that CEBS group was the lowest of all treatments $(P<0.01)$, and that for B. subtilis KT260179 was higher than that for CEBS but lower compared with inorganic $\mathrm{Cr}$ supplementation $(P<0.01)$. The result of TC:HDLC in control was highest of all $(P<0.01)$.

\section{Tissue chromium levels}

The Cr levels in breast meat and blood was measured with results shown in Fig. 5. The results indicated that chickens fed inorganic $\mathrm{Cr}$ had significantly more $\mathrm{Cr}$ in these tissues compared with the control and B. subtilis KT260179 supplementation groups $(P<0.01)$. Chickens in the CEBS group had the highest $\mathrm{Cr}$ levels in those two tissues $(P<0.01)$.

\section{Cecal bacterial composition}

The cecal bacterial composition in the different groups of chickens was examined using the plate method (Table 4).

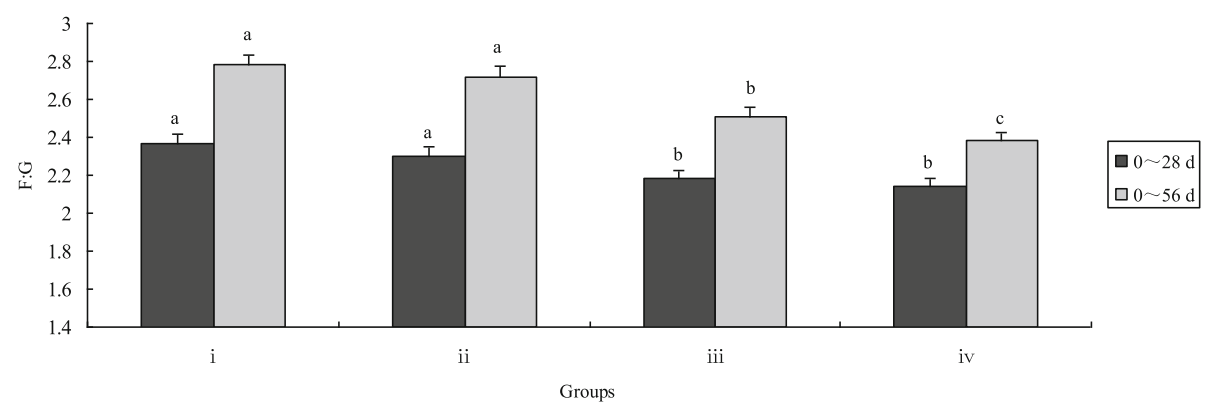

Fig. 4 Effects of different treatments on chicken ratio of feed to gain. The chicken were treated with control (i), inorganic Cr (ii), B. subtilis (iii) and CEBS (iv) after 28 and 56 days. Bars represent mean \pm S.E. Data of Body weight was statistically processed as REPEATED measurements. Bar in same color with different small letters a, b, c mean significant difference at 0.05 levels 
Table 3 Effects of different treatments on chicken breast meat characteristics

\begin{tabular}{|c|c|c|c|c|c|c|}
\hline \multirow[t]{2}{*}{ Groups } & \multicolumn{3}{|l|}{ Meat color } & \multirow[t]{2}{*}{$\mathrm{WHC}^{4}(\%)$} & \multirow[t]{2}{*}{ Shear force $\left(\mathrm{kg} / \mathrm{mm}^{2}\right)$} & \multirow[t]{2}{*}{ Cooking loss (\%) } \\
\hline & $L^{* 1}$ & $a^{* 2}$ & $b^{* 3}$ & & & \\
\hline i & $51.85 \pm 2.11^{\mathrm{a}}$ & $12.63 \pm 0.52^{\mathrm{a}}$ & $16.14 \pm 0.64^{\mathrm{a}}$ & $66.62 \pm 2.42^{a}$ & $2.79 \pm 0.09^{a}$ & $16.89 \pm 0.58^{a}$ \\
\hline ii & $52.27 \pm 2.09^{a}$ & $12.79 \pm 0.50^{\mathrm{a}}$ & $16.85 \pm 0.62^{\mathrm{a}}$ & $70.89 \pm 2.39^{a, b}$ & $2.31 \pm 0.08^{b}$ & $15.96 \pm 0.57^{a, b}$ \\
\hline iii & $54.08 \pm 2.12^{\mathrm{a}}$ & $13.14 \pm 0.51^{\mathrm{a}}$ & $16.92 \pm 0.63^{\mathrm{a}}$ & $71.99 \pm 2.38^{b}$ & $2.24 \pm 0.07^{b}$ & $15.01 \pm 0.51^{b}$ \\
\hline iv & $58.98 \pm 2.08^{b}$ & $15.02 \pm 0.49^{b}$ & $18.49 \pm 0.58^{b}$ & $72.92 \pm 2.40^{b}$ & $1.87 \pm 0.10^{c}$ & $13.22 \pm 0.48^{c}$ \\
\hline
\end{tabular}

The different superscript small letters in the same column $a, b$ mean significant difference at 0.05 levels $(P<0 \cdot 05)$

'Lightness

${ }^{2}$ Redness

${ }^{3}$ Yellowness

${ }^{4}$ Water-holding capacity

Chicken given CEBS or B. subtilis KT260179 had lower numbers of E. coli and Salmonella compared with the control chicken $(P<0.05)$. There were no differences between the control and inorganic $\mathrm{Cr}$-supplemented groups $(P>0.05)$. The numbers of Lactobacillus and Bifidobacterium in the CEBS and B. subtilis KT260179 groups increased significantly compared with the control and inorganic $\mathrm{Cr}$-supplemented groups $(P<0.05)$.

\section{Breast meat quality}

The breast meat quality on color $\mathrm{L}^{*}, \mathrm{a}^{*}, \mathrm{~b}^{*}$, water-holding capacity, shear force and cooking loss were measured with 28-days-old broilers, and the results are provided in Table 5. Chickens with CEBS supplied had higher results of breast meat color $\mathrm{L}^{*}, \mathrm{a}^{*}$ and $\mathrm{b}^{*}(P<0.05)$ than chickens in control, inorganic $\mathrm{Cr}$ and B. subtilis KT260179 groups $(P<0.05)$. Birds supplemented with CEBS and B. subtilis KT260179 had higher water-holding capacity and lower cooking loss than control group $(P<0.05)$. In further, the index of cooking loss in CEBS group was lowest of all $(P<0.05)$. The results of shear force in all three treatment groups were lower than that of control $(P$ $<0.05)$. Also, the result of CEBS group was lowest of all $(P<0.05)$.

\section{Discussion}

Both of $\mathrm{Cr}$ and B. subtilis own the ability of modulating growth performance to chicken $[14,17,18]$. In our study, we supplemented a dose of $0.2 \mu \mathrm{g} / \mathrm{g} \mathrm{CrCl}_{3}$ to basic feedstuff, which demonstrated that there was no promoting effect to Chinese Huainan Partridge chicken. Our results indicated that rates of growth were improved in chickens given B. subtilis KT260179 or CEBS supplements. Whereas chickens supplemented with CEBS had higher average body weights and greater feed utilization efficiency than controls. The F/G index of the CEBS group was the lowest over the entire feeding period, suggesting that this treatment was more efficient than $B$. subtilis alone in regulating body growth performance.

Dietary supplementary $\mathrm{Cr}$ and $\mathrm{B}$. subtilis could improve body lipid metabolism [19-21]. Our data suggested that the concentration of plasma total cholesterol and triglycerides were decreased in chicken treated with CEBS or B. subtilis. CEBS enhanced the metabolism of TC and triglyceride. HDLC, synthesized mainly in the liver and the small intestine, plays an important part in eliminating serum cholesterol [22]. The decreased content of serum lipid resulted from a decrease of TG synthesis and/or enhancement of TG hydrolysis

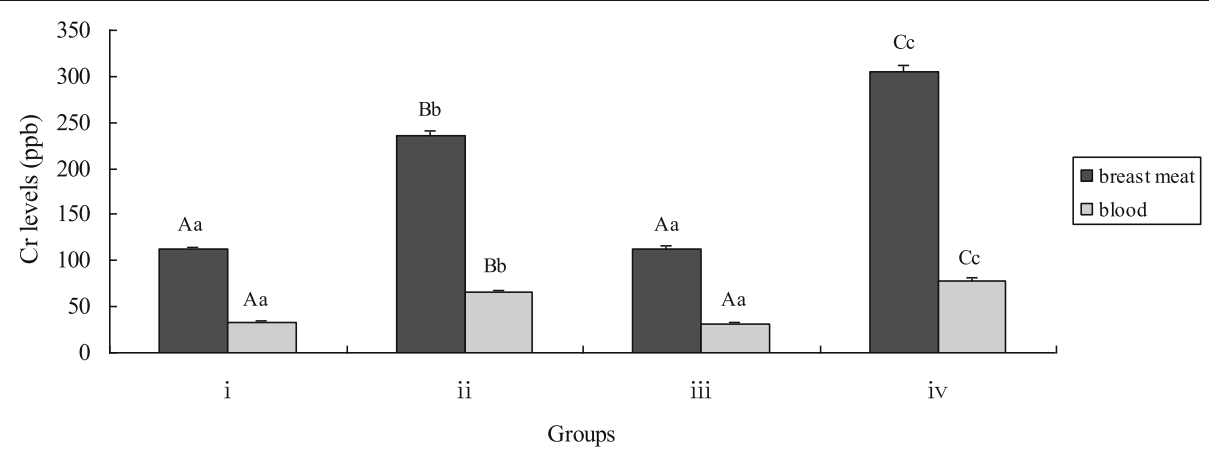

Fig. 5 Effects of different treatments on chicken tissue chromium levels. The chicken were treated with control (i), inorganic Cr (ii), B. subtilis (iii) and CEBS (iv) after 28 and 56 days. Bars represent mean \pm S.E. Data of Body weight was statistically processed as REPEATED measurements. Bar in same color with different small letters $\mathrm{Aa}, \mathrm{Bb}$ mean significant difference at 0.01 levels $(P<0.01)$ 
Table 4 Effects of different treatments on cecal bacterial composition $\log _{10} \mathrm{CFU} \cdot \mathrm{g}^{-1}$

\begin{tabular}{lcccc}
\hline Groups & Escherichia coli & Salmonella & Lactobacillus & Bifidobacterium \\
\hline i & $7.46 \pm 0.14^{\mathrm{a}}$ & $2.39 \pm 0.03^{\mathrm{a}}$ & $7.91 \pm 0.15^{\mathrm{a}}$ & $7.02 \pm 0.06^{\mathrm{a}}$ \\
ii & $7.42 \pm 0.12^{\mathrm{a}}$ & $2.33 \pm 0.03^{\mathrm{a}}$ & $7.93 \pm 0.16^{\mathrm{a}}$ & $7.05 \pm 0.08^{\mathrm{a}}$ \\
iii & $6.92 \pm 0.13^{\mathrm{b}}$ & $1.92 \pm 0.04^{\mathrm{b}}$ & $8.38 \pm 0.16^{\mathrm{b}}$ & $7.24 \pm 0.06^{\mathrm{b}}$ \\
iv & $6.88 \pm 0.13^{\mathrm{b}}$ & $1.88 \pm 0.03^{\mathrm{b}}$ & $8.37 \pm 0.13^{\mathrm{b}}$ & $7.26 \pm 0.05^{\mathrm{b}}$ \\
\hline
\end{tabular}

The different superscript small letters in the same column $a, b$ mean significant difference at 0.05 levels $(P<0.05)$

[23]. The decreased concentrations of hepatic TG revealed that lipid synthesis was reduced when the broilers were fed the $B$. subtilis supplemented diet, which can be associated with the improvement of plasma lipid metabolism. Likewise, supplementary inorganic $\mathrm{Cr}$ could improve the lipid metabolism to a slightly extent. Supplementation $\mathrm{Cr}$ in diet could modify the lipid metabolism especially in obesity or stress condition. The background of the supplementation of $\mathrm{Cr}$ in diabetic or fat persons is the tendency to lose the ability to convert $\mathrm{Cr}$ into a form that potentiates insulin action [24]. Therefore, nutritional supplements could decrease the lipid paraments in plasma [25]. For healthy animals, supplementary $\mathrm{Cr}$ would have little effect on lipid metabolism in a $\mathrm{Cr}$ sufficient diet.

Previous studies have reported that $\mathrm{Cr}$ supplementation can increase the $\mathrm{Cr}$ content of tissues, although the results varied [26, 27]. In our study, the Cr contents of breast meat and blood were very significantly increased with the inorganic and CEBS supplemented. Our results here showed that the supplemental $\mathrm{Cr}$ in CEBS had a significant influence on $\mathrm{Cr}$ content of breast muscle in agreement with a previous report [28]. The effect of CEBS was greater than for inorganic $\mathrm{Cr}$ in this experiment, suggesting that CEBS had greater bioavailability as a $\mathrm{Cr}$ resource. The possible mechanism was that $B$. subtilis grew in medium contained inorganic $\mathrm{Cr}$, to allow the efficient conversion of inorganic $\mathrm{Cr}$ into organic forms, such as amino acid chelated $\mathrm{Cr}$, organic compounds are absorbed more efficiently than are inorganic forms Hence, CEBS owed more bioavailability than inorganic $\mathrm{Cr}[19,29]$.

Probiotic supplements have been reported to modify the composition of the caecal microbiota [30, 31]. Similarly, our results here indicated that $B$. subtilis supplements could alter the bacterial flora in the caeca of treated chicken. Supplementation of $10^{5}$ to $10^{9}$ colonyforming units (CFU)/g of probiotics in the diet could exert beneficial effects in broilers [32]. However, Huang reported that a higher inclusion level did not always result in enhanced performance in poultry [33]. There were reports on supplemental doses 28 , which suggested that $10^{6} \mathrm{CFU}$ of Bacillus per gram feedstuff were suitable. In the present study, we supplemented $10^{6} \mathrm{CFU} / \mathrm{g}$ B. subtilis. The total $\mathrm{Cr}$ concentration in the CEBS treatment was $30 \mu \mathrm{g} / \mathrm{g}$; we therefore added a $0.67 \%$ supplement to the feedstuff, which conform the reported supplementary dose $(0.2 \mu \mathrm{g} \mathrm{Cr}$ per gram feedstuff $)$ $[34,35]$.

When probiotics are used for meat quality enhancement, the effects have been questioned, and many different results have been shown. Some authors reported advantages of probiotic supplementation [36, 37], whereas others reported no beneficial effects [38]. Meat quality could be modified by the improvement of $\mathrm{Cr}$ utilization and intestinal bacterial composition. Our result indicated that with B. subtilis supplemented there were no significances on meat color. While, dietary addition of CEBS could improve meat color, which advised that $\mathrm{CEBS}$ combined the virtue of $\mathrm{Cr}$ and $B$. subtilis regulating the nutrition metabolism strongly. In the measurement of meat quality, water-holding capacity, shear force and drip loss are important factors because some nutrients may be lost in the exudate by water loss, which may be reflected in the juiciness, tenderness, and flavor of meat [39]. In our results, index of water-holding capacity were significantly improved with B. subtilis and CEBS supplemented. Likewise, indexes of shear force and drip loss were significantly lowered. Those results suggested that $B$.

Table 5 Effects of different treatments on plasma lipid parameters

\begin{tabular}{lllllll}
\hline Groups & TC mmol/L & TG mmol/L & LDLC mmol/L & TC/LDLC & HDLC mmol/L & TC/HDLC \\
\hline i & $3.54 \pm 0.11^{\mathrm{a}}$ & $1.21 \pm 0.05^{\mathrm{a}}$ & $1.58 \pm 0.06^{\mathrm{a}}$ & $2.22 \pm 0.06^{\mathrm{Aa}}$ & $0.62 \pm 0.03^{\mathrm{a}}$ & $5.70 \pm 0.13^{\mathrm{Aa}}$ \\
ii & $3.47 \pm 0.10^{\mathrm{a}}$ & $1.15 \pm 0.04^{\mathrm{a}}$ & $1.51 \pm 0.05^{\mathrm{a}}$ & $2.29 \pm 0.05^{\mathrm{Aa}}$ & $0.65 \pm 0.02^{\mathrm{a}}$ & $5.33 \pm 0.12^{\mathrm{Bb}}$ \\
iii & $3.25 \pm 0.12^{\mathrm{b}}$ & $0.97 \pm 0.05^{\mathrm{b}}$ & $1.26 \pm 0.04^{\mathrm{b}}$ & $2.57 \pm 0.04^{\mathrm{Bb}}$ & $0.74 \pm 0.03^{\mathrm{b}}$ & $4.39 \pm 0.14^{\mathrm{CC}}$ \\
iv & $3.03 \pm 0.09^{\mathrm{c}}$ & $0.82 \pm 0.03^{\mathrm{c}}$ & $1.16 \pm 0.04^{\mathrm{c}}$ & $2.61 \pm 0.05^{\mathrm{Cc}}$ & $0.92 \pm 0.03^{\mathrm{c}}$ & $3.29 \pm 0.11^{\mathrm{Dd}}$ \\
\hline
\end{tabular}

TC total cholesterol, TG triglycerides, LDLC low density lipoprotein cholesterol, HDLC high density lipoprotein cholesterol, TC/LDLC ratio of TC to LDLC, TC/HDLC ratio of TC to HDLC

The different superscript small letters in the same column ${ }^{\mathrm{a}, \mathrm{b}, \mathrm{c}}$ mean significant difference at 0.05 levels $(P<0.05)$. ${ }^{\mathrm{Aa}}, \mathrm{Bb}, \mathrm{Cc}$ mean significant difference at 0.01 levels $(P<0.01)$ 
subtilis supplied in feedstuff modified the breast meat quality. The effect of CEBS was greater than for $\mathrm{CrCl}_{3}$ and B. subtilis in the present experiment.

\section{Conclusions}

The results of our study indicated that feeding supplementary CEBS combined the benefits of $\mathrm{Cr}$ and probiotics could improve chicken final body weight and ADG, decrease F:G, compared with control group. While there were no significances on ADFI. Chicken supplemented with CEBS could modify plasma lipid parameters, enhance tissue $\mathrm{Cr}$ concentrations and improve caecal bacterial composition and breast meat quality.

\author{
Abbreviations \\ $a^{*}$ : Redness; ADG: Average daily weight gain; $b^{*}$ : Yellowness; $B$. \\ subtilis: Bacillus subtilis; CEBS: Chromium enriched bacillus subtilis; \\ Cr: Chromium; F/G: Ratio of feed to gain; HDLC: High density lipoprotein \\ cholesterol; L*: Lightness; LDLC: Low density lipoprotein cholesterol; TC: Total \\ cholesterol; TG: Triglycerides; WHC: Water-holding capacity
}

\section{Acknowledgements}

The authors sincerely thank Mr. Kun Qian for his help in presentation of this manuscript.

\section{Funding}

This work was sponsored by the fund of doctor startup project in Anhui Academy of Agricultural Sciences of China. The funders had no role in the design of the study and collection, analysis, and interpretation of data and in writing of the manuscript.

\section{Availability of data and materials}

The datasets supporting the conclusions of this article are included within the article.

\section{Authors' contributions}

$J J Y$ carried out the animal experiments and data analysis, and drafted the manuscript. KQ revised the manuscript. WZ and YYX participated in the animal trial. YJW helped with sample harvested and collection. All authors read and approved the final manuscript.

\section{Competing interests}

The authors declare that they have no competing interests.

\section{Ethics approval and consent to participate}

The experimental protocol used in this study, including animal management, housing, and slaughter procedures, was approved by the Institution of Animal Science and Welfare of Anhui Province (Number: IASWAP2014110528).

Received: 23 August 2016 Accepted: 21 October 2016

\section{Published online: 08 November 2016}

\section{References}

1. Havenstein G, Ferket P, Qureshi M. Growth, livability, and feed conversion of 1957 versus 2001 broilers when fed representative 1957 and 2001 broiler diets. Poult Sci. 2003;82(10):1500-8.

2. Havenstein G, Ferket P, Qureshi M. Carcass composition and yield of 1957 versus 2001 broilers when fed representative 1957 and 2001 broiler diets. Poult Sci. 2003;82(10):1509-18.

3. Le Bihan-Duval E, Millet N, Remignon H. Broiler meat quality: effect of selection for increased carcass quality and estimates of genetic parameters. Poult Sci. 1999;78(6):822-6.

4. Mertz W. Chromium in human nutrition: a review. J Nutr. 1993;123(4):626-33.

5. Lukaski HC. Chromium as a supplement. Annu Rev Nutr. 1999;19:279-302.

6. Laschinsky N, Kottwitz K, Freund B, Dresow B, Fischer R, Nielsen P. Bioavailability of chromium (III)-supplements in rats and humans. Biometals. 2012;25(5):1051-60.
7. Eybe T, Audinot JN, Udelhoven T, Lentzen E, El Adib B, Ziebel J, Hoffmann L, Bohn T. Determination of oral uptake and biodistribution of platinum and chromium by the garden snail (Helix aspersa) employing nano-secondary ion mass-spectrometry. Chemosphere. 2013:90(6):1829-38.

8. Khochamit N, Siripornadulsil S, Sukon P, Siripornadulsil W. Antibacterial activity and genotypic-phenotypic characteristics of bacteriocin-producing Bacillus subtilis KKU213: potential as a probiotic strain. Microbiol Res. 2015; 170:36-50.

9. Kritas SK, Marubashi T, Filioussis G, Petridou E, Christodoulopoulos G, Burriel AR, Tzivara A, Theodoridis A, Piskorikova M. Reproductive performance of sows was improved by administration of a sporing bacillary probiotic (Bacillus subtilis C-3102). J Anim Sci. 2015;93(1):405-13.

10. Lei K, Li YL, Wang Y, Wen J, Wu HZ, Yu DY, Li WF. Effect of dietary supplementation of Bacillus subtilis B10 on biochemical and molecular parameters in the serum and liver of high-fat diet-induced obese mice. J Zhejiang Univ Sci B. 2015;16(6):487-95.

11. National Research Council. Nutrient Requirement of Poultry. 9th ed. Washington D.C.: National Academy Press; 1994.

12. Afridi HI, Kazi TG, Talpur FN, Arain S, Arain SS, Kazi N, Panhwar AH, Brahman $\mathrm{KD}$. Evaluation of chromium and manganese in biological samples (scalp hair, blood and urine) of tuberculosis and diarrhea male human immunodeficiency virus patients. Clin Lab. 2014;60(8):1333-41.

13. Mountzouris KC, Tsirtsikos P, Kalamara E, Nitsch S, Schatzmayr G, Fegeros K. Evaluation of the efficacy of a probiotic containing Lactobacillus, Bifidobacterium, Enterococcus, and Pediococcus strains in promoting broiler performance and modulating cecal microflora composition and metabolic activities. Poult Sci. 2007;86(2):309-17.

14. Jeong JS, Kim IH. Effect of Bacillus subtilis C-3102 spores as a probiotic feed supplement on growth performance, noxious gas emission, and intestinal microflora in broilers. Poult Sci. 2014;3(12):3097-103.

15. Wierbicki E, Deatherage FE. Determination of water-holding capacity of fresh meats. Agric Food Chem. 1958;6:387-92.

16. Cason JA, Lyon CE, Papa CM. Effect of Muscle Opposition during Rigor on Development of Broiler Breast Meat Tenderness. Poult Sci. 1997;76(5):785-7.

17. Jahanian R, Rasouli E. Dietary chromium methionine supplementation could alleviate immunosuppressive effects of heat stress in broiler chicks. J Anim Sci. 2015;93(7):3355-63.

18. Lin YC, Huang JT, Li MZ, Cheng CY, Lien TF. Effects of supplemental nanoparticle trivalent chromium on the nutrient utilization, growth performance and serum traits of broilers. J Anim Physiol Anim Nutr (Berl). 2015;99:59-65.

19. Yang J, Xu Y, Qian K, Zhang W, Wu D, Wang C. Effects of chromium-enriched Bacillus subtilis KT260179 supplementation on growth performance, caecal microbiology, tissue chromium level, insulin receptor expression and plasma biochemical profile of mice under heat stress. Br J Nutr. 2016;115(1):774-81.

20. Sadeghi M, Najaf Panah MJ, Bakhtiarizadeh MR, Emami A. Transcription analysis of genes involved in lipid metabolism reveals the role of chromium in reducing body fat in animal models. J Trace Elem Med Biol. 2015;32:45-51.

21. Do HJ, Chung JH, Hwang JW, Kim OY, Lee JY, Shinl MJ. 1-deoxynojirimycin isolated from Bacillus subtilis improves hepatic lipid metabolism and mitochondrial function in high-fat-fed mice. Food Chem Toxicol. 2015;75:1-7.

22. Wang $M Q, X u Z R$, Zha LY, Lindemann MD. Effects of chromium nanocomposite supplementation on blood metabolites, endocrine parameters and immune traits in finishing pigs. Anim Feed Sci Technol. 2007;139(1):69-80

23. Walker SE, Register TC, Appt SE, Adams MR, Clarkson TB, Chen H, Isom S, Franke AA, Kaplan JR. Plasma lipid-dependent and -independent effects of dietary soy protein and social status on atherogenesis in premenopausal monkeys: implications for postmenopausal atherosclerosis burden. Menopause. 2008;15(5):950-7.

24. Wang ZQ, Zhang XH, Russell JC, Hulver M, Cefalu WT. Chromium picolinate enhances skeletal muscle cellular insulin signaling in vivo in obese, insulinresistant JCR:LA-cp rats. J Nutr. 2006;136:415-20.

25. Toghyani M, Shivazad M, Gheisari A, Bahadoran R. Chromium supplementation can alleviate the negative effects of heat stress on growth performance, carcass traits, and meat lipid oxidation of broiler chicks without any adverse impacts on blood constituents. Biol Trace Elem Res. 2012;146:171-80.

26. Prescha A, Krzysik M, Zablocka-Slowinska K, Grajeta H. Effects of exposure to dietary chromium on tissue mineral contents in rats fed diets with fiber. Biol Trace Elem Res. 2014;159(1-3):325-31. 
27. Uyanik F, Eren M, Guclu BK, Sahin N. Effects of dietary chromium supplementation on performance, carcass traits, serum metabolites, and tissue chromium levels of Japanese quails. Biol Trace Elem Res. 2005;103(2): 187-97.

28. Zha LY, Xu ZR, Wang MQ, Gu LY. Effects of chromium nanoparticle dosage on growth, body composition, serum hormones and tissue chromium in Sprague-Dawley rats. J Zhejiang Univ Sci B. 2007;8(5):323-30.

29. Stewart RDH, Griffiths NM, Thomson CD, Robinson MF. Quantitative selenium metabolism in normal New Zealand women. Br J Nutr. 1987;40: $45-54$.

30. Salazar N, Binetti A, Gueimonde M, Alonso A, Garrido P, Gonzalez del Rey C, Gonzalez C, Ruas-Madiedo P, de los Reyes-Gavilan CG. Safety and intestinal microbiota modulation by the exopolysaccharide-producing strains Bifidobacterium animalis IPLA R1 and Bifidobacterium longum IPLA E44 orally administered to Wistar rats. Int J Food Microbiol. 2011:144(3):342-51.

31. Sen S, Ingale SL, Kim YW, Kim JS, Kim KH, Lohakare JD, Kim EK, Kim HS, Ryu $\mathrm{MH}$, Kwon IK, Chae BJ. Effect of supplementation of Bacillus subtilis LS 1-2 to broiler diets on growth performance, nutrient retention, caecal microbiology and small intestinal morphology. Res Vet Sci. 2012;93(1):264-8.

32. Mountzouris KC, Tsitrsikos P, Palamidi I, Arvaniti A, Mohnl M, Schatzmayr G, Fegeros $\mathrm{K}$. Effects of probiotic inclusion levels in broiler nutrition on growth performance, nutrient digestibility, plasma immunoglobulins, and cecal microflora composition. Poult Sci. 2010;89(1):58-67.

33. Huang MK, Choi YJ, Houde R, Lee JW, Lee B, Zhao X. Effects of Lactobacilli and an acidophilic fungus on the production performance and immune responses in broiler chickens. Poult Sci. 2004:83(5):788-95.

34. Anderson RA, Bryden NA, Polansky MM, Richard MP. Chromium supplementation of turkeys: effects on tissue chromium. J Agric Food Chem. 1989:37(1):131-4.

35. Hossain SM, Barreto SL, Silva CG. Growth performance and carcass composition of broilers fed supplemental chromium from chromium yeast. Anim Feed Sci Technol. 1998;71(3):217-28.

36. Mahajan P, Sahoo J, Panda PC. Effect of probiotic (Lacto-Sacc) feeding, packaging methods and season on the microbial and organoleptic qualities of chicken meat balls during refrigerated storage. J Food Sci Technol. 2000; 37(1):67-71

37. Zhou X, Wang Y, Gu Q, Li W. Effect of dietary probiotic, Bacillus coagulans, on growth performance, chemical composition, and meat quality of Guangxi Yellow chicken. Poult Sci. 2010;89(3):588-93.

38. Zhang ZF, Zhou TX, Ao X, Kim IH. Effects of $\beta$-glucan and Bacillus subtilison growth performance, blood profiles, relative organ weight and meat quality in broilers fed maizesoybean meal based diets. Livest Sci. 2012;150(1-3): 419-24

39. Chen H, Dong X, Yao Z, Xu B, Zhen S, Li C, Li X. Effects of prechilling parameters on water-holding capacity of chilled pork and optimization of prechilling parameters using response surface methodology. J Anim Sci. 2012;90(8):2836-41.

\section{Submit your next manuscript to BioMed Central and we will help you at every step:}

- We accept pre-submission inquiries

- Our selector tool helps you to find the most relevant journal

- We provide round the clock customer support

- Convenient online submission

- Thorough peer review

- Inclusion in PubMed and all major indexing services

- Maximum visibility for your research

Submit your manuscript at www biomedcentral.com/submit

) Biomed Central 